\title{
Influence of Herbicide Carrier on the Tolerance of White Bean to Preplant Incorporated and Preemergence Herbicides
}

\author{
Nader Soltani*, Christy Shropshire, Peter H. Sikkema \\ University of Guelph Ridgetown Campus, Ridgetown, Canada \\ Email: "soltanin@uoguelph.ca
}

Received 11 November 2015; accepted 15 January 2016; published 18 January 2016

Copyright @ 2016 by authors and Scientific Research Publishing Inc.

This work is licensed under the Creative Commons Attribution International License (CC BY). http://creativecommons.org/licenses/by/4.0/

(c) (i) Open Access

\begin{abstract}
Nine field trials (five with PPI and four with PRE herbicides) were conducted at Exeter and Ridgetown, Ontario during 2013 to 2015 to determine if the tolerance of white bean to preplant incorporated (PPI) and preemergence (PRE) herbicides is influenced by the herbicide carrier (water vs. UAN at $200 \mathrm{~L} \cdot \mathrm{ha}^{-1}$ ). There was no significant interaction between the carrier and herbicide for visible injury, plant stand, plant height, shoot dry weight, seed moisture content and yield. There was also no significant difference between the herbicide carriers for all parameters measured except for the shoot dry weight which was $6.5 \%$ greater when UAN was used as the carrier with PPI herbicides. Dimethenamid-p, pendimethalin, imazethapyr and halosulfuron applied PPI or PRE caused no visible injury except for imazethapyr PPI which caused $2 \%$ visible injury and dimethenamid-p PRE which caused 7\% - 14\% injury in white bean. There was no effect of the PPI and PRE herbicides evaluated on white bean stand, shoot dry weight, height, maturity and yield. Based on these results, using water or UAN could be used as the carrier for PPI and PRE herbicides in white bean.
\end{abstract}

\section{Keywords}

Dimethenamid-p, Imazethapyr, Navy Bean, Pendimethalin, Halosulfuron

\section{Introduction}

North America is the largest producer of white bean (Phaseolus vulgaris L.) in the world [1]. Most of the white bean produced in Canada is grown in Ontario. In 2014, Ontario white bean growers seeded approximately

\footnotetext{
*Corresponding author.
}

How to cite this paper: Soltani, N., Shropshire, C. and Sikkema, P.H. (2016) Influence of Herbicide Carrier on theTolerance of White Bean to Preplant Incorporated and Preemergence Herbicides. American Journal of Plant Sciences, 7, 63-68. 
30,000 hectares and produced more than 80,000 tonnes of white bean with a farm gate value of approximately $\$ 55,000,000$ [2]. Short stature of white bean makes it not a strong competitor with weeds which can result in substantial seed yield losses, reduce harvest efficiency, and cause staining of the bean [3]-[5]. Common annual weeds in dry bean production in Ontario include redroot pigweed (Amaranthus retroflexus L.), common lambsquarters (Cheno-podium album L.), common ragweed (Ambrosia artemisiifolia L.), velvetleaf (Abutilon theophrasti Medicus), ladysthumb (Polygonum persicaria L.), eastern black nightshade (Solanum ptycanthum Dun.), and annual grasses such as Setaria, Digitaria, Echinochloa, and Panicum species [6]. Research is needed to identify herbicides that have an adequate margin of crop safety, provide consistent weed control, have low environmental impact and maximize dry bean yield and net returns to white bean growers in Ontario.

Dimethenamid-p is a chloroacetamide herbicide that controls annual grasses such as green foxtail (Setaria viridis L.), yellow foxtail (Setaria glauca auct., non (L.) P. Beauv.), giant foxtail (Setaria faberi R. A. W. Herrm.), barnyardgrass (Echinochloa crus-galli (L.) Beauv.), witchgrass (Panicum capillare L.), fall panicum (Panicum dichotomiflorum Michx.), smooth crabgrass (Digitaria ischaemum (Schreb.) ex Muhl.), large crabgrass (Digitaria sanguinalis (L.) Scop.) and some small-seeded broadleaf weeds such as redroot pigweed and eastern black nightshade including triazine- and acetolactate synthase-resistant biotypes [6] [7].

Pendimethalin is a dinitroaniline herbicide that can control annual grasses such as green foxtail, giant foxtail, yellow foxtail, barnyardgrass, smooth crabgrass, large crabgrass, fall panicum and small seeded annual broadleaf weed such as redroot pigweed and common lambsquarters including acetolactate synthase and triazineresistant biotypes [6] [7].

Imazethapyr is an imidiazolinone herbicide that can control annual broadleaf and grass weeds including velvetleaf, redroot pigweed, common lambsquarters, wild mustard (Sinapsis arvensis L.), common ragweed, Eastern black nightshade, wild buckwheat (Polygonum convolvulus L.) including triazine-tolerant biotypes [6] [7].

Halosulfuron is a sulfonylurea herbicide that controls nutsedge species (Cyperus spp.), redroot pigweed, common lambsquarters, wild mustard, ladysthumb, velvetleaf and cocklebur (Xanthium strumarium L.), including triazine resistant biotypes [6] [7].

Nitrogen fertilizer such as $28 \%$ liquid urea-ammonium nitrate solution (UAN) is often used at low rates with postemergence (POST) herbicides to improve herbicide absorption [8]. The use of UAN with POST herbicides has been shown to increase injury in some crops under some environments [8]-[14]. There is little information on the influence of UAN at $200 \mathrm{~L} \cdot h a^{-1}$ as the carrier for the PPI or PRE application of dimethenamid-p, pendimethalin, imazethapyr or halosulfuron in white bean under Ontario environmental conditions. In addition, co-application of UAN with herbicides such as dimethenamid-p, pendimethalin, imazethapyr and halosulfuron will reduce the number of trips across the field resulting in fuel and labaour savings as well as reducing wear and tear on machinery and soil compaction. Determining the influence of UAN as the herbicide carrier with these herbicides can help maximize herbicide application efficiency, dry bean yield and net returns to Ontario dry bean producers.

The objectives of this study are to determine if the tolerance of white bean to dimethenamid-p, pendimethalin, imazethapyr and halosulfuron applied preplant incorporated or preemergence are influenced by the herbicide carrier (water vs. UAN at $200 \mathrm{~L} \cdot \mathrm{ha}^{-1}$ ).

\section{Materials and Methods}

Nine field trials (five with PPI and four with PRE herbicides) were conducted at the Huron Research Station, Exeter, Ontario and University of Guelph Ridgetown Campus, Ridgetown, Ontario during 2013 to 2015. The soil at Exeter was a Brookston clay loam (Orthic Humic Gleysol, mixed, mesic, and poorly drained) and the soil at Ridgetown was a Watford (Grey to Brown Brunisolic, mixed, mesic, sandy, and imperfectly drained)-Brady (Gleyed Brunisolic Grey to Brown Luvisol, mixed, mesic, sandy, and imperfectly drained) sandy loam. Seedbed preparation at all sites consisted of autumn moldboard plowing followed by seedbed preparation and herbicide incorporation with a S-tine cultivator with rolling basket harrows in the spring.

The experiments were arranged in a randomized complete block design with treatments replicated four times. PPI and PRE trials were side by side. Treatments for PPI and PRE trials included a weed-free control and dimethenamid-p (693 $\mathrm{g}$ ai ha $\left.{ }^{-1}\right)$, pendimethalin (1080 $\mathrm{g}$ ai ha $\left.{ }^{-1}\right)$, imazethapyr $\left(75 \mathrm{~g}\right.$ ai ha $\left.{ }^{-1}\right)$ and halosulfuron (35 g ai ha ${ }^{-1}$ ) applied with UAN or water as the carrier at $200 \mathrm{~L} \cdot \mathrm{ha}^{-1}$. Each plot was $3.0 \mathrm{~m}$ wide and $10 \mathrm{~m}$ (Exeter) or 8 $\mathrm{m}$ (Ridgetown) long and consisted of four rows of “T9905” white bean spaced $0.75 \mathrm{~m}$ apart. White bean was 
planted at approximately 250,000 seeds $\cdot \mathrm{ha}^{-1}$ in late May to early June.

Herbicide treatments were applied using a $\mathrm{CO}_{2}$-pressurized backpack sprayer calibrated to deliver $200 \mathrm{~L} \cdot \mathrm{ha}^{-1}$ at $240 \mathrm{kPa}$. The boom was $1.5 \mathrm{~m}$ long with four ultra-low drift nozzles (ULD120-02, Hypro, New Brighton, MN) spaced $50 \mathrm{~cm}$ apart. The surface area sprayed was the center $2.0 \mathrm{~m}$ of each plot by $10.0 \mathrm{~m}$ (Exeter) or $8 \mathrm{~m}$ (Ridgetown) in length. There was a $1.0 \mathrm{~m}$ unsprayed area between adjacent plots. PPI and PRE herbicides were applied 1 - 2 days before planting (incorporated immediately) and 1 - 2 days after planting, respectively. Weed-free controls were maintained with inter-row cultivation and hand hoeing during the growing season.

Estimates of white bean injury were visually estimated on a scale of 0 (no injury) to $100 \%$ (complete plant death) at 1, 2 and 4 weeks after crop emergence (WAE). White bean stand and dry weight were determined 3 WAE by counting and cutting the plants from $1 \mathrm{~m}$ of row per plot at the soil surface, drying at $60 \mathrm{C}$ to constant moisture and then weighing. From this information, white bean weight per plant was also calculated. At 6 WAE, white bean height was measured for 10 plants per plot. The bean crop was harvested with a small plot combine, weight and seed moisture were recorded, and yields were adjusted to $18 \%$ moisture.

Data were analyzed as a 2-way factorial using PROC MIXED in SAS 9.4. Factor 1 was herbicide carrier (water or UAN) and factor 2 was herbicide treatment (dimethenamid-p, pendimethalin, imazethapyr, halosulfuron). Trials in which herbicides were applied PPI were analyzed separately from those applied PRE. Fixed effects included the two treatment factors, herbicide carrier and herbicide treatment, as well as their interaction; random effects included year-location combinations (environment), interactions between environment and the fixed effects, and replicate nested within environment. Significance of fixed effects was tested using F-tests and random effects were tested using a Z-test of the variance estimate. The UNIVARIATE procedure was used to test data for normality and homogeneity of variance. To satisfy the assumptions of the variance analyses, injury 1, 2 and 4 WAE (PRE application) and injury 1 WAE (PPI application) were square root transformed, injury 4 WAE (PPI application) was arcsine square root transformed, and dry weights and seed moisture (PRE and PPI applications) were log transformed. For all injury ratings, the untreated check (assigned a value of zero) was excluded from the analysis. However, all values were compared independently to zero to evaluate treatment differences with the untreated check. Treatment comparisons were made using Fisher's Protected LSD at a level of $P<0.05$ and any data compared on the transformed scale were converted back to the original scale for presentation of results.

\section{Results and Discussion}

There were no visible incompatibility problems in respect to the herbicide carrier (water or UAN) and the herbicides evaluated in this study (data not shown).

\subsection{Preplant Incorporated Herbicides}

There was no significant interaction between the carrier and herbicide for visible injury, plant stand, plant height, shoot dry weight, seed moisture content and yield (Table 1). There was also no significant difference between the herbicide carriers for visible injury, plant stand, plant height, seed moisture content and yield. However, shoot dry weight was $6.5 \%$ greater when UAN was used as the herbicide carrier compared to the water carrier (Table 1).

Dimethenamid-p, pendimethalin, imazethapyr and halosulfuron applied preplant incorporated caused no injury in white at 1 and 2 WAE. However, at 4 WAE imazethapyr caused slightly more injury than dimethenamid-p, pendimethalin and halosulfuron (Table 1). There was no effect of the herbicides evaluated on white bean stand, shoot dry weight, height, maturity and yield (Table 1). Results are similar to other studies that have shown no injury in white bean with halosulfuron applied PPI with water as the carrier [15]-[19]. However, in other studies, halosulfuron, applied PPI with water as the carrier caused $58 \%$ to $70 \%$ injury in adzuki bean and reduced adzuki bean height $52 \%$ to $70 \%$ and caused as much as $8 \%$ injury in snap bean and reduced yield as much as $15 \%$ [15] [20].

\subsection{Preemergence Herbicides}

There was no significant interaction between the carrier and herbicide for white bean visible injury, plant stand, 
Table 1. Main effects and interaction for white bean injury, plant stand, dry weight, height, seed moisture at harvest and yield with herbicides applied PPI in water or UAN. Means followed by the same letter within a column are not significantly different according to Fisher's Protected LSD at $P<0.05$. Means for a main effect were separated only if there was no significant interaction involving that main effect. ${ }^{\mathrm{a}}$

\begin{tabular}{|c|c|c|c|c|c|c|c|c|c|c|}
\hline & & & Injury & & & & & & & \\
\hline \multirow[t]{2}{*}{ Main Effects ${ }^{b}$} & & $1 \mathrm{WAE}$ & 2 WAE & 4 WAE & Plant Stand & \multicolumn{2}{|c|}{ Dry Weight } & \multirow{2}{*}{$\begin{array}{c}\text { Height } \\
\mathrm{cm}\end{array}$} & \multirow{2}{*}{$\begin{array}{c}\text { Moisture } \\
\%\end{array}$} & \multirow{2}{*}{$\begin{array}{c}\text { Yield } \\
\text { MT ha }{ }^{-1}\end{array}$} \\
\hline & & & $\%$ & & no $\mathrm{m}^{-1}$ row $^{-1}$ & $\mathrm{~g} \mathrm{~m}^{-1}$ row $^{-1}$ & g plant $^{-1}$ & & & \\
\hline Herbicide carrier & & NS & NS & NS & NS & $*$ & NS & NS & NS & NS \\
\hline Water & & 0 & 1 & 0 & 18 & $30 \mathrm{~b}$ & 1.8 & 56 & 18.9 & 3.45 \\
\hline UAN & & 1 & 1 & 0 & 18 & $32 \mathrm{a}$ & 1.9 & 57 & 19.0 & 3.53 \\
\hline Herbicide treatment & Rate $\left(g a i h a^{-1}\right)$ & NS & NS & * & NS & NS & NS & NS & NS & NS \\
\hline Untreated check & & 0 & 0 & $0 \mathrm{a}$ & 18 & 32 & 1.9 & 56 & 19.0 & 3.48 \\
\hline Dimethenamid-p & 693 & 1 & 1 & $0 \mathrm{a}$ & 19 & 29 & 1.7 & 56 & 18.9 & 3.48 \\
\hline Pendimethalin & 1080 & 0 & 0 & $0 \mathrm{a}$ & 18 & 34 & 2.0 & 58 & 18.6 & 3.53 \\
\hline Imazethapyr & 75 & 0 & 1 & $2 \mathrm{~b}$ & 18 & 30 & 1.7 & 54 & 19.5 & 3.47 \\
\hline Halosulfuron & 35 & 0 & 1 & $0 \mathrm{a}$ & 18 & 30 & 1.8 & 58 & 18.8 & 3.49 \\
\hline \multicolumn{11}{|l|}{ Interaction } \\
\hline $\mathrm{C} \times \mathrm{H}$ & & NS & NS & NS & NS & NS & NS & NS & NS & NS \\
\hline
\end{tabular}

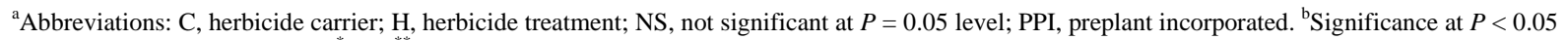
and $P<0.01$ levels denoted by ${ }^{*}$ and ${ }^{* *}$, respectively.

plant height, shoot dry weight, seed moisture content and yield (Table 2). There was also no significant difference between the herbicide carriers for white bean visible injury, plant stand, shoot dry weight, plant height, seed moisture content and yield (Table 2).

Dimethenamid-p applied PRE caused 14\%, 11\% and 7\% visible injury at 1, 2 and 4 WAE in white bean, respectively. However, there was a minimal visible injury ( $2 \%$ or less) with pendimethalin, imazethapyr and halosulfuron applied PRE in white bean at 1, 2 and 4 WAE. Dimethenamid-p, pendimethalin, imazethapyr and halosulfuron applied PRE caused no adverse effect on white bean stand, shoot dry weight, height, seed moisture content and yield (Table 2).

Results are similar to other studies with pendimethalin, dimethenamid-p, imazethapyr and halosulfuron, applied PRE with water as the carrier which showed minimal crop injury and yield reduction in white bean [21]-[24]. Pendimethalin applied PRE has also been shown to cause as little as $1 \%$ crop injury and no yield reduction in white bean [25].

\section{Conclusion}

This study concludes that UAN can be used as the carrier solution for dimethenamid-p, pendimethalin, imazethapyr and halosulfuron applied PPI or PRE and does not cause any incompatibility problems in respect to the spray solution. Herbicide carrier (water or UAN at $200 \mathrm{~L} \cdot \mathrm{ha}^{-1}$ ) has minimal effect on the tolerance of white bean to dimethenamid-p, pendimethalin, imazethapyr and halosulfuron applied preplant incorporated or pree-mergence under Ontario environmental conditions. 
Table 2. Main effects and interaction for white bean injury, plant stand, dry weight, height, seed moisture at harvest and yield with various herbicides applied PRE in water or UAN. Means followed by the same letter within a column are not significantly different according to Fisher's Protected LSD at $P<0.05$. Means for a main effect were separated only if there was no significant interaction involving that main effect. ${ }^{a}$

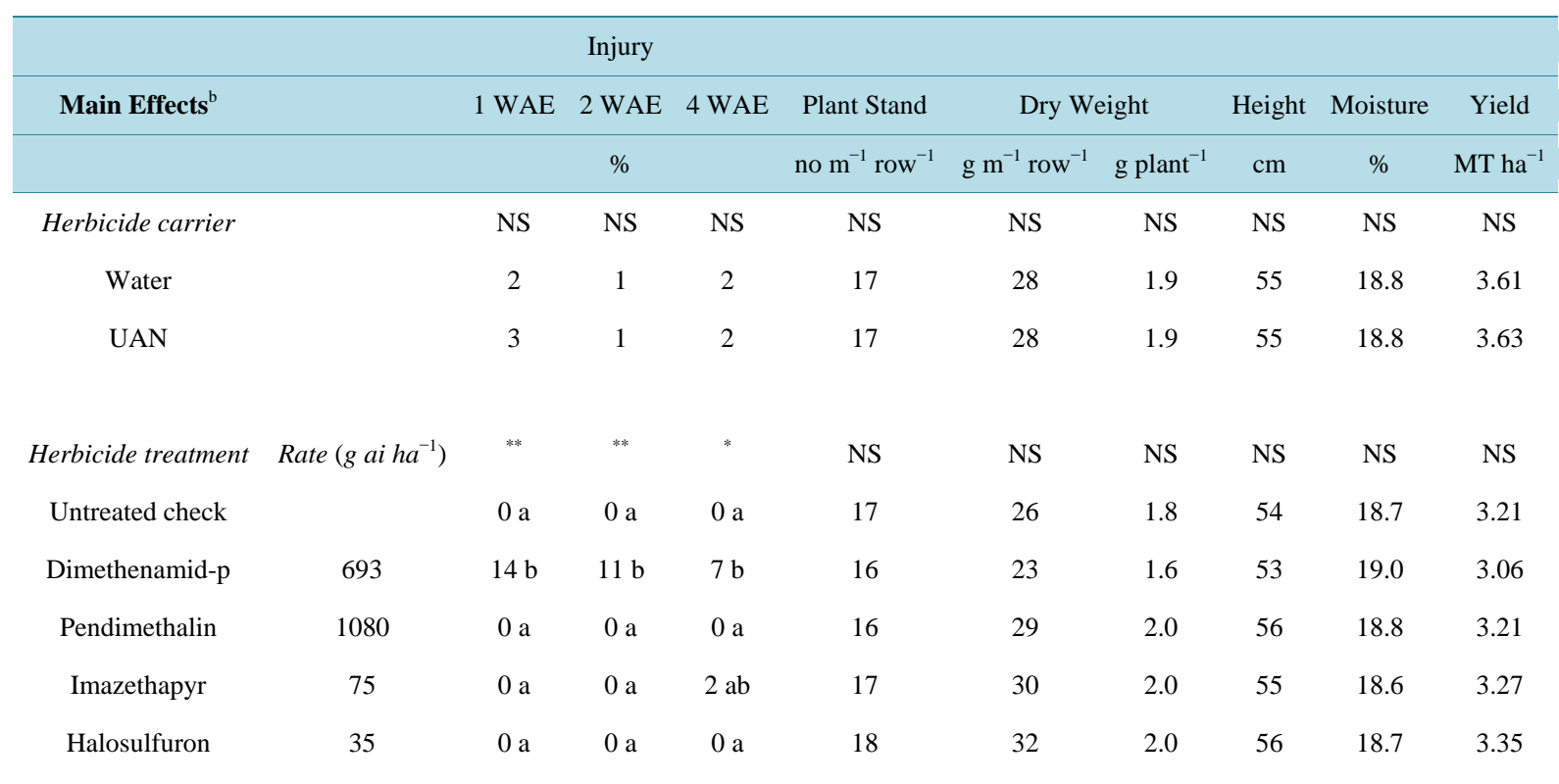

Interaction

$\mathrm{C} \times \mathrm{H}$

NS NS NS NS

NS

NS NS NS

NS

${ }^{\mathrm{a}}$ Abbreviations: $\mathrm{C}$, herbicide carrier; $\mathrm{H}$, herbicide treatment; NS, not significant at $P=0.05$ level; PRE, preemergence. ${ }^{\mathrm{b}}$ Significance at $P<0.05$ and $P$ $<0.01$ levels denoted by ${ }^{*}$ and ${ }^{* *}$, respectively.

\section{Acknowledgements}

The authors would like to acknowledge Todd Cowan for his expertise and technical assistance in these studies. Funding for this project was provided by the Ontario Bean Growers and the Growing Forward II of the Agricultural Adaptation Council.

\section{References}

[1] Breuer, T. (2002) The Emerging Bean, Harvest 2002 Edition. Ontario White Bean Producers, London, 16 p.

[2] Kumuduni, K. (2014) Estimated Area, Yield, Production and Farm Value of Specified Field Crops, Ontario, 2011-2014. Ontario Ministry of Agriculture and Food and Rural Affairs. http://www.omafra.gov.on.ca/english/stats/crops/estimate new.htm\#metric

[3] Chikoye, D., Weise, S.F. and Swanton, C.J. (1995) Influence of Common Ragweed (Ambrosia artemisiifolia) Time of Emergence and Density on White Bean (Phaseolus vulgaris). Weed Science, 43, 375-380.

[4] Malik, V.S., Swanton, C.J. and Michaels, T.E. (1993) Interaction of White Bean (Phaselous vulgaris L.) Cultivars, Row Spacing, and Seeding Density with Annual Weeds. Weed Science, 41, 62-68.

[5] Urwin, C.P., Wilson, R.G. and Mortensen, D.A. (1996) Responses of Dry Edible Bean (Phaseolus vulgaris) Cultivars to Four Herbicides. Weed Technology, 10, 512-518.

[6] Ontario Ministry of Agriculture, Food and Rural Affairs (2014) Guide to Weed Control. Publication 75, Toronto.

[7] Senseman, S.A. (2007) Herbicide Handbook. 9th Edition, Weed Science Society of America, Champaign, 458 p.

[8] Stahlman, P.W., Currie, R.S. and El-Hamid, M.A. (1997) Nitrogen Carrier and Surfactant Increase Foliar Herbicide Injury in Winter Wheat. Weed Technology, 11, 7-12.

[9] Claassen, M.M. and Peterson, D.E. (1993) Cheat Control in Winter Wheat with Triasulfuron and Chlorsulfuronp Lus Metsulfuron. Proc. North Cent.Weed Sci. Soc., 48, 33-34. 
[10] Klein, R.N. and Thrailkill, D.J. (1994) Wild Buckwheat Control in Winter Wheat with Triasulfuron. Proc. West. Soc. Weed Sci., 47, 69-70.

[11] Lutcher, L.K. and Mahler, R.L. (1985) Evaluation of Urea-Ammoniumn Nitrate (UAN) Topdress Applications on Winter Wheat in Northern Idaho. Journal of Fertilisers, 2, 74-79.

[12] Lutcher, L.K. and Mahler, R.L. (1988) Sources and Timing of Spring Topdress Nitrogen on Winter Wheat in Idaho. Agronomy Journal, 80, 648-654. http://dx.doi.org/10.2134/agronj1988.00021962008000040020x

[13] Wicks, G.A., Martin, D.A. and Mahnken, G.W. (1995) Cultural Practices in Wheat (Triticum aestivum) on Weeds in Subsequent Fallow and Sorghum (Sorghum bicolor). Weed Science, 43, 434-444.

[14] Wicks, G.A. and Hergert, G.W. (1992) Effect of Fertilizer plus Herbicide Solution on Winter Wheat. Proceedings of the North Central Weed Science Society, 47, 29-33.

[15] Soltani, N., Nurse, R.E., Shropshire, C. and Sikkema, P.H. (2009) Effect of Halosulfuron Applied Preplant Incorporated, Preemergence, and Postemergence on Dry Bean. Weed Technology, 23, 535-539. http://dx.doi.org/10.1614/WT-09-047.1

[16] Soltani, N., Shropshire, C. and Sikkema, P.H. (2012) Response of Dry Beans to Halosulfuron Applied Postemergence. Canadian Journal of Plant Science, 92, 723-728. http://dx.doi.org/10.4141/cjps2011-220

[17] Soltani, N., Nurse, R.E., Shropshire, C. and Sikkema, P.H. (2012) Weed Control, Environmental Impact and Profitability of Pre-Plant Incorporated Herbicides in White Bean. American Journal of Plant Sciences, 3, 846-853. http://dx.doi.org/10.4236/ajps.2012.37102

[18] Soltani, N., Nurse, R.E., Shropshire, C. and Sikkema, P.H. (2013) Weed Control in White Bean with Pendimethalin Applied Preplant Followed by Postemergence Broadleaved Herbicides. The Open Plant Science Journal, 7, 24-30.

[19] Soltani, N., Nurse, R.E., Shropshire, C. and Sikkema, P.H. (2014) Weed Control in White Bean with Various Halosulfuron Tankmixes. The Advances in Agriculture, 2014, 1-7. http://dx.doi.org/10.1155/2014/391634

[20] Stewart, C.L., Nurse, R.E., Gillard, C. and Sikkema, P.H. (2010) Tolerance of Adzuki Bean to Preplant-Incorporated, Pre-Emergence, and Post-Emergence Herbicides in Ontario, Canada. Weed Biology and Management, 10, 40-47. http://dx.doi.org/10.1111/j.1445-6664.2010.00365.x

[21] Soltani, N., Nurse, R.E., Shropshire, C. and Sikkema, P.H. (2014) Sensitivity of Dry Bean to Dimethenamid-p, Saflufenacil and Dimethenamid-p/Saflufenacil. American Journal of Plant Sciences, 5, 3288-3294. http://dx.doi.org/10.4236/ajps.2014.521343

[22] Soltani, N., Nurse, R.E., Shropshire, C. and Sikkema, P.H. (2014) Weed Control with Halosulfuron Applied Preplant Incorporated, Preemergence or Postemergence in White Bean. Agricultural Science, 5, 875-881. http://dx.doi.org/10.4236/as.2014.510094

[23] Poling, K.W., Renner, K.A. and Penner, D. (2009) Dry Edible Bean Class and Cultivar Response to Dimethenamid and Metolachlor. Weed Technology, 23, 73-80. http://dx.doi.org/10.1614/WT-07-092.1

[24] Soltani, N., Shropshire, C., Cowan, T. and Sikkema, P.H. (2004) White Bean Sensitivity to Preemergence Herbicides. Weed Technology, 18, 675-679. http://dx.doi.org/10.1614/WT-03-130R

[25] Soltani, N., Nurse, R.E., Shropshire, C. and Sikkema, P.H. (2013) Response of Dry Bean to Pendimethalin Applied Preplnat Incorporated or Preemergence. African Journal of Agricultural Research, 8, 4827-4832. 